\title{
In Vitro Regeneration Potential of Thin Cell Layer Explants of Lentisk (Pistacia lentiscus var. Chia) Plant
}

\section{Sakız (Pistacia lentiscus var. Chia) Bitkisine ait İnce Hücre Tabaka Eksplantlarının In Vitro Rejenerasyon Potansiyeli}

\begin{abstract}
Nurberat Çetin ${ }^{*}$, Begüm Güler ${ }^{2}$, Aynur Gürel $^{3}$
Geliş / Received: 04/06/2021

Revize / Revised: 04/11/2021

Kabul / Accepted: 11/11/2021

ABSTRACT

The problems encountered in the production of the lentisk trees, which are one of the important endemic plants of our country have led to the use of biotechnological methods. In this research for this purpose, the TCL (Thin Cell Layer) technique was consideredto investigate of in vitro regeneration potential of expants used for production of lentisk. Firstly, the leaf, node and stem parts of the plant were cut by TCL technique and these explants had been cultured in semi-solid MS media supplemented with 2,4-D and KIN at different concentrations $(0.1,0.2,0.5$ and $1.0 \mathrm{mg} / \mathrm{L})$. The highest callus formation percentage was $100 \%$ in transverse stem layers and longitudinal node in MS media including $1 \mathrm{mg} / \mathrm{L}$ 2,4-D and $1 \mathrm{mg} / \mathrm{L} \mathrm{KIN}$. The lowest callus regeneration ratios were found as $26.67 \%$ for three explant types (transverse leaf, transverse stem, longitudinal node). Due to the high rate of darkening in regenerated calli, these were transferred primarily to semi-solid media containing different antioxidants (ascorbic acid, citric acid, PVP, active charcole) and after that culturedin liquid media containing different plant growth regulators (IAA, KIN and BAP) to induced somatic embryogenesis. Later, the calli were encapsulated to prevent darkening and the nurse technique was applied with Aloe vera L. and Gossypium hirsutum L. calli as a different application. As a result of all these trials, somatic embryogenesis didn't occur, but darkening ratio was reduced to $6.67 \%$.
\end{abstract}

Keywords- Lentisk, TCL, Regeneration, Calli, Darkening

$\overline{\text { öz }}$

Ülkemizin önemli endemik bitkilerinden biri olan sakız ağacının üretiminde yaşanan sorunlar, biyoteknolojik yöntemlerin kullanılmasına yol açmıştır. Bu çalışmada, sakız ağacı üretimine yönelik olarak kullanılan eksplantların in vitro rejenerasyon potansiyellerinin incelenmesi amacıyla, TCL (İnce Hücre Tabaka) tekniği ele alınmıştır. İlk olarak, bitkinin yaprak, nod ve gövde kısımları TCL tekniği ile kesilmiş ve bu eksplantlar, farklı konsantrasyonlarda $(0.1,0.2,0.5$ ve $1.0 \mathrm{mg} / \mathrm{L})$ 2,4-D ve KIN ile desteklenmiş yarı katı MS ortamında kültüre alınmışlardır. En yüksek kallus oluşum yüzdesi, enine gövde ve boyuna nod eksplantlarında $\% 100$ olarak $1 \mathrm{mg} / \mathrm{L}$ 2,4-D ve $1 \mathrm{mg} / \mathrm{L} \mathrm{KIN} \mathrm{içeren} \mathrm{MS} \mathrm{ortamında} \mathrm{elde} \mathrm{edilmiştir.} \mathrm{En} \mathrm{düşük} \mathrm{kallus} \mathrm{rejenerasyon} \mathrm{oranları} \mathrm{ise,} \mathrm{üç} \mathrm{eksplant}$ tipinde (enine yaprak, enine gövde, boyuna nod) \%26,67 olarak bulunmuştur. Rejenere olan kalluslardaki yüksek kararma oranı nedeniyle, bu kalluslar öncelikle farklı antioksidanlar (askorbik asit, sitrik asit, PVP, aktif karbon)

\footnotetext{
1*Sorumlu yazar iletişim: nurberatcetin@gmail.com (https://orcid.org/0000-0003-0887-7758) Ege Üniversitesi, Fen Bilimleri Enstitüsü, Biyomühendislik Anabilim Dall, İzmir, Türkiye 2iletişim: begumakyol@ege.edu.tr (https://orcid.org/0000-0002-9970-2111) Ege Üniversitesi, Fen Bilimleri Enstitüsü, Biyomühendislik Anabilim Dall, İzmir, Türkiye 3iletișim: aynurgurel@ege.edu.tr (https://orcid.org/0000-0002-7002-9752) Ege Üniversitesi, Fen Bilimleri Enstitüsü, Biyomühendislik Anabilim Dalı, İzmir, Türkiye
} 
içeren yarı katı ortamlara aktarılmışlardır ve ardındansomatik embriyogenezi başlatmak için farklı bitki büyüme düzenleyicileri (IAA, KIN ve BAP) içeren sıvı ortamlarda kültüre alınmışlardır. Daha sonrasında kararmayı önlemek için kalluslar enkapsüle edilmişlerdir ve ayrıca farklı bir uygulama olarak Aloe vera $\mathrm{L}$. yaprakları ve Gossypium hirsutum L. kallusları ile nörs tekniği uygulanmıştır. Tüm bu denemeler sonucunda somatik embriyogenezmeydana gelmemiştir, ancak kararmalar \%6,67’ye kadar azalmıştır.

\section{Anahtar Kelimeler-Sakız ă̆acı, TCL, Rejenerasyon, Kallus, Kararma}

\section{I.INTRODUCTION}

The lentisk (Pistacia lentiscus L.) belongs to the Pistacia genus of the Anacardiaceae family, which are hermaphrodite, polygamodioic or dioecious trees, shrubs, woody vines and perennial plants that secrete resin from the canals in the tree trunk, branches or leaves, which darken when injured [1]. Browicz [2] were declared that the culture forms in Chios are not selected according to the variety but the variety that has been selected according to the yield for many years. Some researchers only mention the "Chia" variety in Chios as a resin-producing plant [3]. Even though wild forms of lentisk are abundant in natural conditions, and there is a more limited spread of $P$. lentiscus L. var. Chia, is a species used in the production of mastic and is suitable for tree form [4]. This tree, also known as the "immortal tree", gets old after 70 years and its mastic yield decreases. Lentisk grown with modern agricultural techniques takes less time to mature and come to mastic yield earlier [5]. Although the original species has a widespread, the culture of the lentisk has been carried out only in the south of Chios Island in Greece and around the Çeşme district of Izmir, which is opposite this island [6-9]. World-famous gum mastic (Natural gum resin) and Chios (Chios) names did not come about by chance. Chios is a word of Phoenician origin. It means 'mastic' (natural gum resin). It is known that the word mastic-masticha comes from the Greek verb "masticate (chew), "maso" or "mastix". Chewing gum has contributed to the commercial importance of the island [6].

Production of lentisk by traditional methods carried out by germination of seeds, rooting of cuttings, grafting or layering. Since the tree is dichotomous, the probability of being male or female in seedlings that grow from seed is half shares. There is also a genetic opening. For this reason, it is a disadvantage that it loses the elite features of the variety. Since male varieties are required to obtain chewing gum, this possibility may result negatively [10]. Since the seed coat prevents germination due to the structure that prevents the embryo's development, it must be carefully removed or subjected to scarification. For this purpose, soaking in hot/cold water, physical (seed coat breaking, cracking, sanding, etc.) applications, application of various chemicals (sulfuric acid, hydrochloric acid etc.) or keeping in different contentrations and different periods in gibberellic acid which is one of the plant growth regulators are some of the pre-germination process [11]. Because of plants from in vivo propagation process, formed as a shrub, this shrub form should also be transformed into tree form. The products obtained from the very few lentisk gardens established by traditional methods for tree propagation are insufficient to meet the demands. For this reason, it is beneficial to support existing reproduction techniques with biotechnological methods [6].

Plant tissue culture; can be defined as the cultivation of plant cells, tissues and organs using artificial nutrients in a controlled and aseptic environment [12,13]. Among plant tissue culture techniques, micropropagation is the most popular, academic and commercial technique [14]. Micropropagation is a technique that is taken from a plant and used to rapidly reproduce a large number of genetically similar plants from plant parts (seeds, stems, embryos, etc.) that can form entire plants in artificial nutrients and under aseptic conditions [15]. Plant regeneration is the final and desired result of plant tissue culture based on the principle of totipotency. This regeneration can be achieved by organogenesis and somatic embryogenesis. Differentiation types occurring in all plants provide shoot and root production with tissue culture techniques. Together, these two events are called organogenesis. In some cases these two events occur in a self-regulated way. The name given to this is somatic or adventitious embryogenesis [16,17]. Plants transform from a unicellular zygote into a multicellular organism through coordinated cell divisions, and when this process occurs without modelling, irregular callus tissue is produced [18]. The concept of TCL was born when Tran Thanh Van manipulated the size and position of the explant to control this organogenic potential better using the tobacco plant $[19,20]$. In the Thin Cell Layer (TCL) system, cells that have nuclei in their cytoplasm are controlled individually or reprogrammed in a cellular logic to differentiate [21]. TCL technique can be applied in two different ways. Although these have different advantages in different plants, the most used type is the transverse thin cell layer (tTCL) and the other is the longitudinal thin cell layer technique (ITCL). The tTCL technique regenerates mini-rhizomes, mass reproduction, germplasm 
conservation, and secondary metabolites [22,23]. The ITCL technique has been beneficial in adventitious root formation and xylogenesis and their investigation [24].

TCL technology is a method that improves tissue culture and facilitates clonal propagation. With this method, it is possible to obtain higher yields than traditional in vitro methods [25]. TCL culture can induce specific morphogenic pathways such as controlled somatic embryo production [26]. This technique offers an excellent opportunity to evaluate the differentiation and totipotency level in cells, tissues and organs in plants. It also enables the mass production of economically important species and has lucrative advantages [27]. Compared to traditional explants, the use of TCLs for morphogenesis, due to lower levels of endogenous plant growth regulators, more efficient transport of media components to target cells may result in earlier morphogenesis or a higher proportionof morphogenic cells compared to the total number of cells of the explant [28]. This technique is an alternative for plants that show little or no regeneration in vitro. In addition, this delicate cell/tissue system can be beneficial if very valuable medicinal, commercial or ornamental plants do not tend to regenerate again. Another last possibility is to use explants that are not strictly used for a particular type of organogenesis or embryogenesis, but are of different origin from the organ or tissue types that only show low efficiency [29].

The working capacity of a TCL technique depends on several factors, including accurate signal detection and transmission. The capacity of genetic systems to respond to these signals depends on the plant's physiological state, explant type, applied stress factors, etc. couldbe varied. If cells can detect the correct signal, they phenotypically differentiate into normal organs [18]. TCLs; has been used for tissue culture of several dozen plants of commercial importance including orchids, tobacco, field crops (cereals, rapeseed, rice), horticulture (fruits, vegetables, ornamentals), herbs and even forest trees (Pinus sp.) and woody fruit plants (Citrus spp. and apple). Yet the lack of available applications for such a simple model system for basic crops such as wheat or potatoes or for a wider range of medicinal and pharmaceutically important species, or other woody tree species such as sandalwood (Santalum album), which may have become extinct potential of this technique sufficiently unexplored [24].

One of the most critical problems in establishing in vitro cultures in Pistacia species is rapid darkening and explant necrosis caused by these reasons. In addition, due to the exudation of phenolics to the medium, necrosis of explants and shoot organogenesis are also inhibited [30]. The most important reason of the darkening problem is the oxidation of polyphenols. The phenylalanine ammoniasis (PAL), a key enzyme in the phenylpropanoid pathway, is triggered by injury to plant tissues. PAL inhibitors can control the darkening of tissues [31]. Various compounds can be used for this purpose. The most used of these are citric and ascorbic acid. These compounds can reduce quinones formed by the action of oxidases; therefore, they prevent the formation of dark colour pigments and can act as inhibitors of enzymes by lowering the $\mathrm{pH}$ and separating the ion in the oxidase prosthetic group [32]. Ascorbic acid (AA) is known as a beneficial agent against cold and other stresses. Also, AA is characterized as a signal transduction molecule that can act independently or transmit ROS (reactive oxygen species) signals. Ascorbic acid regulates the cell cycle and affects growth through elongation growth. As ascorbic acid causes cells to transition from G1 to the S phase, its participation in growth and development is clear [33].

In the studies conducted by [34] on the Pistacia lentiscus plant, the best nutrient medium for both root and leaf explants in callus culture initiation trials was MS (80\% and 84\% percent callus generation, respectively), the best combination of plant growth regulators $1 \mathrm{mg} / \mathrm{L} \mathrm{KIN}$ and $1 \mathrm{mg} / \mathrm{L} \mathrm{2,4-D}$ has been determined. Among the experiments on the development of callus cultures for both root $(80 \%)$ and leaf (100\%) explant sources the best nutrient medium has been full strength MS medium. [35] obtained the best-packed cell volume and dry weight values in MS medium containing $1 \mathrm{mg} / \mathrm{L} \mathrm{KIN} \mathrm{and} 1 \mathrm{mg} / \mathrm{L} \mathrm{2,4-D} \mathrm{in} \mathrm{the} \mathrm{cell} \mathrm{suspension} \mathrm{trials} \mathrm{they} \mathrm{performed} \mathrm{in}$ Pistacia lentiscus. [36] In their study, it was transferred to a liquid MS salt solution containing $0.4 \mathrm{M}$ sucrose, $3 \%$ $\mathrm{Na}-\mathrm{Alg}$, and did not contain $\mathrm{Ca}^{+2}$, then dropped into $100 \mathrm{mM} \mathrm{CaCl} 2.2 \mathrm{H}_{2} 0$ solution and waited for 25 minutes. They were incubated in petri dishes which were contained MS nutrient medium for varying times $(2,4,6,9$ and 12 months). It has been decided that the best storage period is 6 months.

Lentisk; is a very valuable plant with its pleasant appearance and medicinal and chemical properties. It is one of the most popular medicinal plants both in our country and around the world. Gum resin is a precious and alternative resource for the pharmaceutical industry, especially with its pharmaceutical properties. Biotechnological methods are needed since production is done in a very limited and their reproduction is difficult. This study, it is aimed to regenerate this valuable plant with TCL technique, which is one of the modern plant tissue culture techniques. Using this technique, it was attempted to examine the in vitro regeneration responses of 
different plant tissues in different plant growth regulator concentrations and modify the optimum nutrient media compositions.

\section{MATERIALS AND METHODS}

\section{A. Plant Material and Culture Conditions}

Within the scope of this study, three different bush form plants belonging to Pistacia lentiscus var. Chia male plants in Ege University Bioengineering Department were used as starting material. Stem, node and leaf explants were taken from these plants at regular intervals as an explant source, and culture initiations were made (Figure 1). MS [37], Woody Plant Medium (WPM) [38], Rugini Olive Medium (ROM) [39] compositions were used for the in vitro cultures (Table 1). The cultures whose experiments were established were preserved at 16 hours light $/ 8$ hours dark photoperiod, $24 \pm 2{ }^{\circ} \mathrm{C}$ and 3500 lux light intensity.

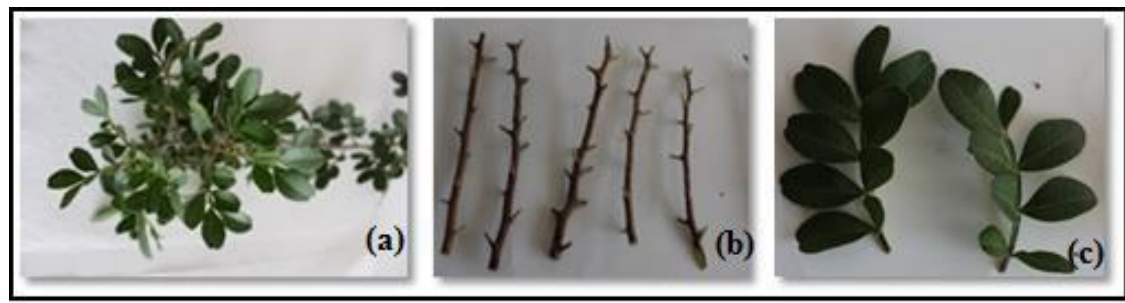

Figure 1. Lentisk explants (a) cut branches (b) branches without leaves (c) leaves

Table 1. MS, ROM and WPM media compositions

\begin{tabular}{|c|c|c|c|}
\hline \multirow{2}{*}{ Medium composition } & \multicolumn{3}{|c|}{ The amount required in $1 \mathrm{~L}(\mathrm{mg} / \mathrm{L})$} \\
\hline & MS & ROM & WPM \\
\hline $\mathrm{NH}_{4} \mathrm{NO}_{3}$ & 1650 & 412 & 400 \\
\hline $\mathrm{Ca}\left(\mathrm{NO}_{3}\right)_{2} \cdot 4 \mathrm{H}_{2} \mathrm{O}$ & 0 & 600 & 460 \\
\hline $\mathrm{CaCl}_{2} \cdot 2 \mathrm{H}_{2} \mathrm{O}$ & 440 & 440 & 72 \\
\hline $\mathrm{MgSO}_{4} \cdot 7 \mathrm{H}_{2} \mathrm{O}$ & 370 & 1500 & 370 \\
\hline $\mathrm{KNO}_{3}$ & 1900 & 1100 & 2500 \\
\hline $\mathrm{KH}_{2} \mathrm{PO}_{4}$ & 170 & 340 & 168 \\
\hline $\mathrm{K}_{2} \mathrm{SO}_{4}$ & 0 & 0 & 988 \\
\hline $\mathrm{KCl}$ & 0 & 500 & 0 \\
\hline $\mathrm{H}_{3} \mathrm{BO}_{3}$ & 6,2 & 12,4 & 6,2 \\
\hline $\mathrm{CuSO}_{4} .5 \mathrm{H}_{2} \mathrm{O}$ & 0,025 & 0,25 & 0,025 \\
\hline $\mathrm{MnSO}_{4} \cdot \mathrm{H}_{2} \mathrm{O}$ & 16,9 & 22,3 & 16,9 \\
\hline $\mathrm{Na}_{2} \mathrm{MoO}_{4} \cdot 2 \mathrm{H}_{2} \mathrm{O}$ & 0,25 & 0,25 & 0,25 \\
\hline $\mathrm{ZnSO}_{4} \cdot 7 \mathrm{H}_{2} \mathrm{O}$ & 8,6 & 14,3 & 8,6 \\
\hline $\mathrm{FeSO}_{4} \cdot 7 \mathrm{H}_{2} \mathrm{O}$ & 27,8 & 27,8 & 28 \\
\hline $\mathrm{Na}_{2}$.EDTA & 37,3 & 37,5 & 15 \\
\hline $\mathrm{KI}$ & 0,83 & 0,83 & 0,83 \\
\hline $\mathrm{CoCl}_{2} \cdot 6 \mathrm{H}_{2} \mathrm{O}$ & 0,025 & 0,025 & 0,025 \\
\hline Thiamine $\mathrm{HCl}$ & 0,1 & 0,5 & 0,1 \\
\hline Nicotinic asit & 0,5 & 5 & 0,5 \\
\hline $\mathrm{HCl}$ & 0,5 & 0,5 & 0,5 \\
\hline Glycine & 2 & 2 & 2 \\
\hline Glutamine & 0 & 2190 & 0 \\
\hline Biotin & 0 & 0,05 & 0 \\
\hline Myo-inositol & 100 & 100 & 100 \\
\hline
\end{tabular}




\begin{tabular}{|c|c|c|}
\hline & $\begin{array}{l}\text { BŞEÜ Fen Bilimleri Dergisi } \\
8(2), 960-977,2021\end{array}$ & $\begin{array}{r}\text { BSEU Journal of Science } \\
\text { https://doi.org/10.35193/bseufbd.947888 }\end{array}$ \\
\hline ERS & & 2458-7575 (https://dergipark.org.tr/tr/pub/bseufbd) \\
\hline
\end{tabular}

\section{B. Sterilization}

The explants taken from the trees were cut, the nodes and leaves were separated, and the stem segments were roughly cut and put into three different containers. For pre-sterilization, explants were rinsed vigorously with detergent water for 15 minutes, and then rinsed under running water for 10 minutes. After being taken into the laminar flow cabinet, the pores were opened with $70 \%$ ethyl alcohol for 1 minute. They were then treated with a mercury chloride solution $\left(\mathrm{HgCl}_{2}\right)$ at a concentration of $0.1 \%$ for 7 minutes. Finally, the explant sources, which were rinsed for 1 minute each, and purified from mercury chloride by passing through sterile distilled water, were transferred to the application of the thin cell layer technique.

\section{Regeneration Experiments with Different Types of Lentisk Explants Using TCL Technique}

For obtained regenerations via TCl technique, MS medium including a combination of different concentrations 2,4-D and KIN, were used with different explant types (node, stem and leaf). Leaf tissues taken within the scope of this technique were taken in a cross-section of approximately 1-1.5 mm, with the main vein structure of the leaf in the middle. For stem TCLs, mainly internodes of fresh tissues near the shoot tip were used as donors, the thickness of a stem explant was cut transversely at 0.5-1 mm thickness and cultured. For stem TCLs, mainly internodes of fresh tissues near the shoot tip were used as donors. The thickness of a stem explant was cut transversely at $0.5-1 \mathrm{~mm}$ thickness and cultured. For the node TCLs, the node parts are cut lengthwise with the TCL technique, and care has been taken to ensure that both cut parts were equal. All of the explants whose cutting was completed were transferred to the cultures so that the cut surfaces were in contact with the medium (Table 2).

Table 2. Media compositions for different explant sources

\begin{tabular}{llllll}
\hline \multirow{2}{*}{\begin{tabular}{l} 
Plant $\begin{array}{c}\text { growth } \\
\text { regulators and } \\
\text { concentrations }\end{array}$ \\
\cline { 3 - 6 }
\end{tabular}} & $\mathbf{0 , 1}$ & $\mathbf{0 , 2}$ & $\mathbf{0 , 5}$ & $\mathbf{1}$ \\
\hline & $\mathbf{0 , 1}$ & $\mathrm{N} 1$ & $\mathrm{~N} 2$ & $\mathrm{~N} 3$ & $\mathrm{~N} 4$ \\
$\mathbf{K I N}$ & $\mathbf{0 , 2}$ & $\mathrm{N} 5$ & $\mathrm{~N} 6$ & $\mathrm{~N} 7$ & N8 \\
$(\mathbf{m g} / \mathbf{L})$ & $\mathbf{0 , 5}$ & $\mathrm{N} 9$ & $\mathrm{~N} 10$ & N11 & N12 \\
& $\mathbf{1}$ & N13 & N14 & N15 & N16 \\
\hline
\end{tabular}

\section{Callus Tissue Transfers to Semi-solid Media for Regeneration and Preventing Darkening}

All cultures, which were observed every 15 days, were transferred to a new medium at the end of 60 days to regenerate the callus tissues where organogenesis did not occur. The study, it was observed that both the tissue of the lentisk and the newly formed callus masses tend to darken. For this reason, antioxidants have been added to prevent or eliminate darkening in the new media to be transferred. Antioxidants used in antioxidant experiments were added to ROM (R16) and WPM (W16) based nutrient media, except for N16, which was stated to show the best callus growth. The growth regulator combinations of the media were kept the same as the N16 nutrient medium ( $1 \mathrm{mg} / \mathrm{L}$ 2,4-D + $1 \mathrm{mg} / \mathrm{L}$ KIN). The antioxidant combinations given in Table 3 were added to the new nutrient medium codes and new experiments codes were created. For example, if $\mathrm{F}$ antioxidant combination is used in the N16 nutrient medium, it is named N16F.

Table 3. Antioxidant combinations

\begin{tabular}{lllll}
\hline \multirow{2}{*}{$\begin{array}{l}\text { Concentration } \\
(\mathbf{m g} / \mathbf{L})\end{array}$} & \multicolumn{3}{c}{ Type } \\
\cline { 2 - 5 } & $\begin{array}{l}\text { Ascorbic } \\
\text { acid }\end{array}$ & $\begin{array}{l}\text { Citric } \\
\text { acid }\end{array}$ & $\begin{array}{l}\text { Polyvinylpyrrolidone } \\
\text { (PVP) }\end{array}$ & $\begin{array}{l}\text { Active } \\
\text { charcole }\end{array}$ \\
\hline $\mathbf{1 0 0}$ & A & C & - & G \\
$\mathbf{5 0 0}$ & B & D & - & H \\
$\mathbf{1 0 0 0}$ & - & - & E & J \\
$\mathbf{2 0 0 0}$ & - & - & F & K \\
\hline
\end{tabular}

\section{E. Callus Tissue Transfers to Liquid Media for Inducing Somatic Embryogenesis}

Liquid cultures with continuous immersion were established to ensure the regeneration of healthy callus tissues obtained from the lentisk. Callus tissues taken from semi-solid media were weighed $0.5 \mathrm{gr}$ taken and 
transferred into $50 \mathrm{~mL}$ of liquid medium. The medium compositions used are given in Table 4. Liquid cultures in flasks placed on the orbital shaker were set to $100 \mathrm{rpm}$ indefinitely and incubated.

Table 4. Liquid media compositions

\begin{tabular}{cccc}
\hline No & IAA $(\mathbf{m g} / \mathbf{L})$ & KIN $(\mathbf{m g} / \mathbf{L})$ & BAP (mg/L) \\
\hline MS1I & 1 & 0 & 0 \\
MS1K & 0 & 1 & 0 \\
MS1I1K & 1 & 1 & 0 \\
MS1I1B & 1 & 0 & 1 \\
MS1K1B & 0 & 1 & 1 \\
MS1I1K1B & 1 & 1 & 1 \\
\hline
\end{tabular}

\section{G. Encapsulation of Callus Tissue}

Synthetic seed culture experiments have been established to block the darkening of callus tissues taken from semi-solid media by cutting off their contact with oxygen. $50 \mathrm{mM}$ calcium chloride $\left(\mathrm{CaCl}_{2}\right)$ solution and four different sodium alginate solutions were used to harden of the synthetic seed beads. Ascorbic acid and citric acid have been added to the sodium alginate solution to block the darkening (Table 5). The N16 medium, which was determined as the best callus medium for the control group, was prepared by adding $4 \%$ sodium alginate. The calli were cut into pieces approximately $2-3 \mathrm{~mm}$ in size and pieces were thrown into the sodium alginate mixtures. The callus pieces, which remained in the solution for a short time, were poured into $\mathrm{CaCl}_{2}$ solutions drop by drop, while mixed and turned into a sphere and waited for 5 minutes. After the beads were purified from $\mathrm{CaCl} 2$ solution, they were transferred to the nutrient media in the jar (Figure 2).

Table 5. Ascorbic acid and citric acid concentrations added to the sodium alginate solutions

\begin{tabular}{ccc}
\hline $\begin{array}{c}\text { odium alginate } \\
\text { solution }\end{array}$ & Ascorbic acid (mg/L) & Citric acid (mg/L) \\
\hline NA1 & 0 & 0 \\
NA2 & 100 & 0 \\
NA3 & 0 & 100 \\
NA4 & 100 & 100 \\
\hline
\end{tabular}

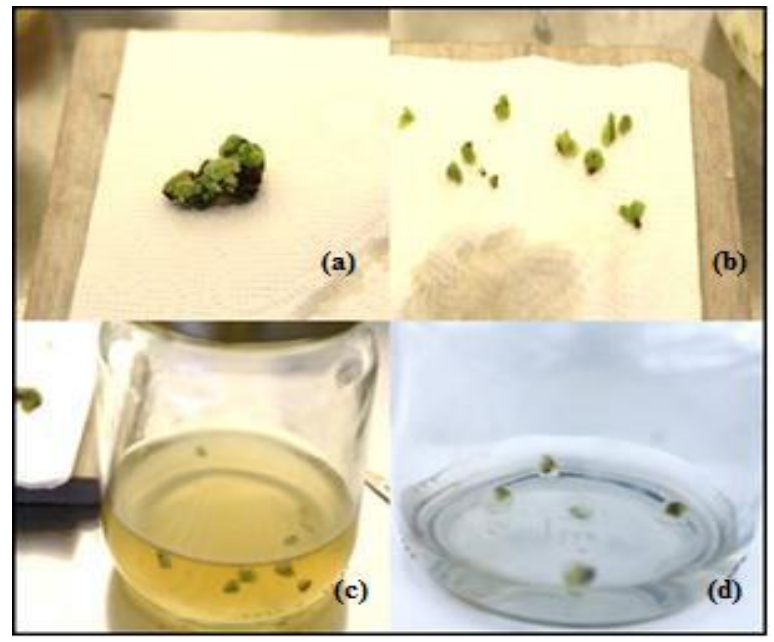

Figure 2. (a) Callus tissue to be coated with alginate (b) Callus tissue with green parts divided into small pieces (c) callus pieces were taken into $\mathrm{CaCl}_{2}$ solution to become spheres (d) Spherical beads transferred to the nutrient medium 


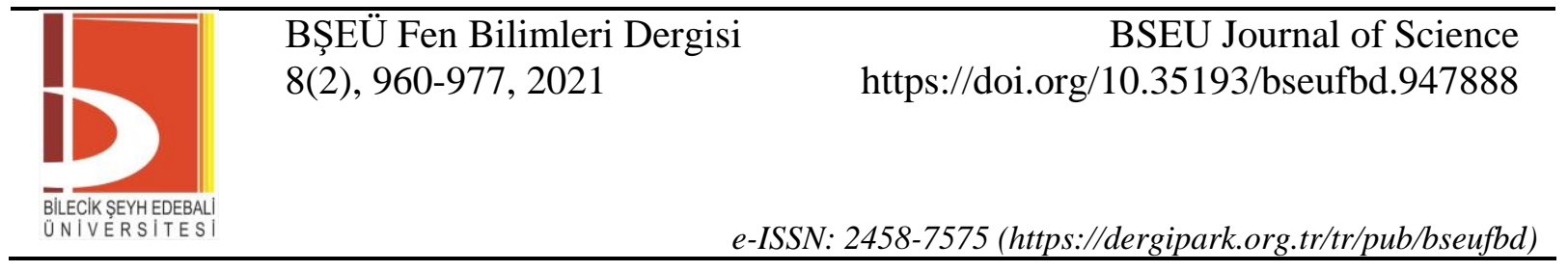

\section{H. Application of Aloe vera L. Leaf Tissues as a Nurse Tissue}

To prevent the lentisk callus tissues from darkening and to determine the possibility of supporting their regeneration, nurse cultures were established with Aloe vera $\mathrm{L}$. plant tissues, known for their nourishing and healing effects. For this purpose, each leaf piece of in vitroAloe Vera L. plant is cut in 1-1.5 cm length and width. Callus tissues were placed in clumps in cultures containing N16 nutrient medium with gel portions up and down and coded as AVa (a) and (b) as AVb in Figure 3.

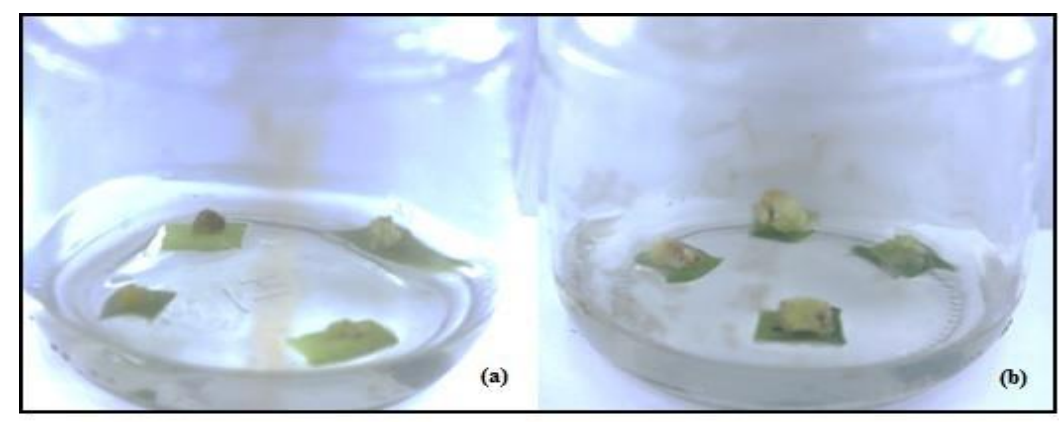

Figure 3. Callus tissues placed on epidermis layers (a) and on the gel (b) of Aloe vera L. pieces in vitro conditions

\section{Application of Gossypium hirsutum L. Callus as a Nurse Tissue}

In this experiment, which was established similar to the previous experiment, a nurse culture was tried with a different plant (Gossypium hirsutum L.) callus. Lentisk callus was placed on in vitro cotton callus taken in N16 nutrient medium in three clusters. The experiments were set up with two different methods, with sterile filter paper between them and callus placed directly, and coded as (a) shape PKa and (b) shape PKb (Figure 4).

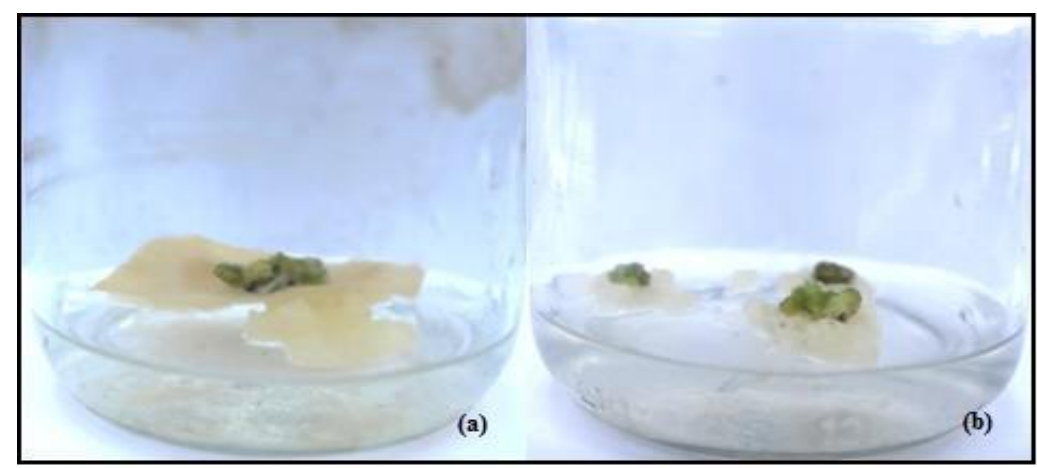

Figure 4.In vitro lentisk tissues (a) placed after placing filter paper on Gossypium hirsutum L. callus (b) callus tissues directly placed on callus tissue

\section{J. Statistical Analysis}

The trials were carried out in three replications according to the randomized plot design. Data from applications, Minitab 18 (Minitab ${ }^{\circledR}$, LLC, Pennsylvania, USA, 2017) was evaluated using the statistics program. The effects of the trials were tested with one-way analysis of variance (ANOVA). Differences between the means of the trial results Comparison of the means when found to be statistically significant was made based on the 5\% error limit according to Duncan test and expressed in different letters.

\section{III.RESULT}

\section{A. Regeneration Experiments with Different Types of Lentisk Explants Using TCL Technique}

TCL technique was applied from three different explant sources in lentisk plant. When leaf (transverse), stem (transverse) and node (longitudinal) starting explants were cultured in 16 different semi-solid medium, direct organogenesis or indirect organogenesis was not observed in any of the nutrient media experiments. The contamination (\%) (Table 6) and darkening (\%) (Table 7) of the experiments varying according to the medium and explant sources were found to be insignificant according to the variance analysis results. Callus formation was 
observed in all experiments regardless of the type of explant (Figure 5). It has been observed that all of the calli have a tight structure. The two-way analysis of variance of the callus formation status of the experiments varying according to the medium and explant sources is given in the Table 8, and the difference was found to be significant.

Table 6. Average contamination (\%) of callus tissues formed by different explant sources (transverse leaf and stem sections, longitudinal node sections) at the end of 6 weeks culture period in different media

\begin{tabular}{|c|c|c|c|}
\hline \multirow{2}{*}{ Media compositions } & \multicolumn{3}{|c|}{ Explant sources } \\
\hline & Transverse leaf sections & Transverse stem sections & Longitudinal node sections \\
\hline N1 & 26,67 & 20 & 20 \\
\hline N2 & 20 & 20 & 20 \\
\hline N3 & 20 & 20 & 20 \\
\hline N4 & 13,33 & 20 & 13,33 \\
\hline N5 & 26,67 & 6,67 & 6,67 \\
\hline N6 & 33,33 & 6,67 & 6,67 \\
\hline N7 & 6,67 & 13,33 & 13,33 \\
\hline N8 & 6,67 & 13,33 & 20 \\
\hline N9 & 13,33 & 13,33 & 13,33 \\
\hline N10 & 13,33 & 20 & 13,33 \\
\hline N11 & 13,33 & 13,33 & 13,33 \\
\hline N12 & 20 & 20 & 20 \\
\hline N13 & 6,67 & 13,33 & 6,67 \\
\hline N14 & 6,67 & 20 & 20 \\
\hline N15 & 6,67 & 6,67 & 6,67 \\
\hline N16 & 13,33 & 13,33 & 13,33 \\
\hline
\end{tabular}

* Trials were carried out in 3 replications and each repeat contains 5 explants. Significant differences between the mean values were evaluated at the $\mathrm{P}=0.05$ level using the MiniTab program, according to the ANOVA multiple comparison test.

Table 7. Average darkening $(\%)$ ratios of different explant sources determined after 6 weeks of culture period in different media*

\begin{tabular}{cccc}
\hline \multirow{2}{*}{ Media compositions } & \multicolumn{3}{c}{ Explant sources } \\
\cline { 2 - 4 } N1 & Transverse leaf sections & Transverse stem sections & Longitudinal node sections \\
\hline N2 & 13,33 & 20 & 13,33 \\
N3 & 13,33 & 6,67 & 6,67 \\
N4 & 13,33 & 13,33 & 13,33 \\
N5 & 20 & 20 & 13,33 \\
N6 & 6,67 & 6,67 & 6,67 \\
N7 & 26 & 13,33 & 13,33 \\
N8 & 6,67 & 6,67 & 6,67 \\
N9 & 6,67 & 13,33 & 13,33 \\
N10 & 6,67 & 6,67 & 6,67 \\
N11 & 13,33 & 13,33 & 13,33 \\
N12 & 13,33 & 6,67 & 13,33 \\
N13 & 13,33 & 6,67 & 13,33 \\
N14 & 20 & 20 & 20 \\
N15 & 20 & 13,33 & 13,33 \\
N16 & 20 & 20 & 20
\end{tabular}

* Trials were carried out in 3 replications and each repeat contains 5 explants. Significant differences between the mean values were evaluated at the $\mathrm{P}=0.05$ level using the MiniTab program, according to the ANOVA multiple comparison test. 
Table 8. Average callus formation $(\%)$ ratios of different explant sources determined after 6 weeks of culture period in different media*

\begin{tabular}{|c|c|c|c|}
\hline \multirow{2}{*}{ Media compositions } & \multicolumn{3}{|c|}{ Explant sources } \\
\hline & Transverse leaf sections & Transverse stem sections & Longitudinal node sections \\
\hline $\mathrm{N} 1$ & $73,33 a b$ & $80,00 a b$ & $80,00 a b$ \\
\hline $\mathrm{N} 2$ & $60,00 a b$ & $80,00 a b$ & $46,67 \mathrm{ab}$ \\
\hline N3 & $53,33 a b$ & $46,67 \mathrm{ab}$ & $53,33 a b$ \\
\hline N4 & $33,33 \mathrm{ab}$ & $33,33 \mathrm{ab}$ & $33,33 \mathrm{ab}$ \\
\hline N5 & $26,67 \mathrm{~b}$ & $40,00 \mathrm{ab}$ & $40,00 \mathrm{ab}$ \\
\hline N6 & $26,67 \mathrm{~b}$ & $40,00 \mathrm{ab}$ & $40,00 \mathrm{ab}$ \\
\hline N7 & $33,33 \mathrm{ab}$ & $33,33 \mathrm{ab}$ & $33,33 \mathrm{ab}$ \\
\hline N8 & $40,00 \mathrm{ab}$ & $40,00 \mathrm{ab}$ & $40,00 \mathrm{ab}$ \\
\hline N9 & $33,33 \mathrm{ab}$ & $60,00 \mathrm{ab}$ & $60,00 \mathrm{ab}$ \\
\hline N10 & $46,67 \mathrm{ab}$ & $46,67 \mathrm{ab}$ & $46,67 \mathrm{ab}$ \\
\hline N11 & $46,67 \mathrm{ab}$ & $66,67 \mathrm{ab}$ & $66,67 \mathrm{ab}$ \\
\hline N12 & $26,67 b$ & $26,67 \mathrm{~b}$ & $26,67 b$ \\
\hline $\mathrm{N} 13$ & $80,00 \mathrm{ab}$ & $86,67 \mathrm{ab}$ & $80,00 \mathrm{ab}$ \\
\hline $\mathrm{N} 14$ & $66,67 \mathrm{ab}$ & $66,67 \mathrm{ab}$ & $66,67 \mathrm{ab}$ \\
\hline N15 & $73,33 \mathrm{ab}$ & $73,33 \mathrm{ab}$ & $73,33 \mathrm{ab}$ \\
\hline N16 & $86,67 a b$ & $100 \mathrm{a}$ & $100 \mathrm{a}$ \\
\hline
\end{tabular}

* Trials were carried out in 3 replications and each repeat contains 5 explants. Significant differences between the mean values were evaluated at the $\mathrm{P}=0.05$ level using the MiniTab program, according to the ANOVA multiple comparison test.

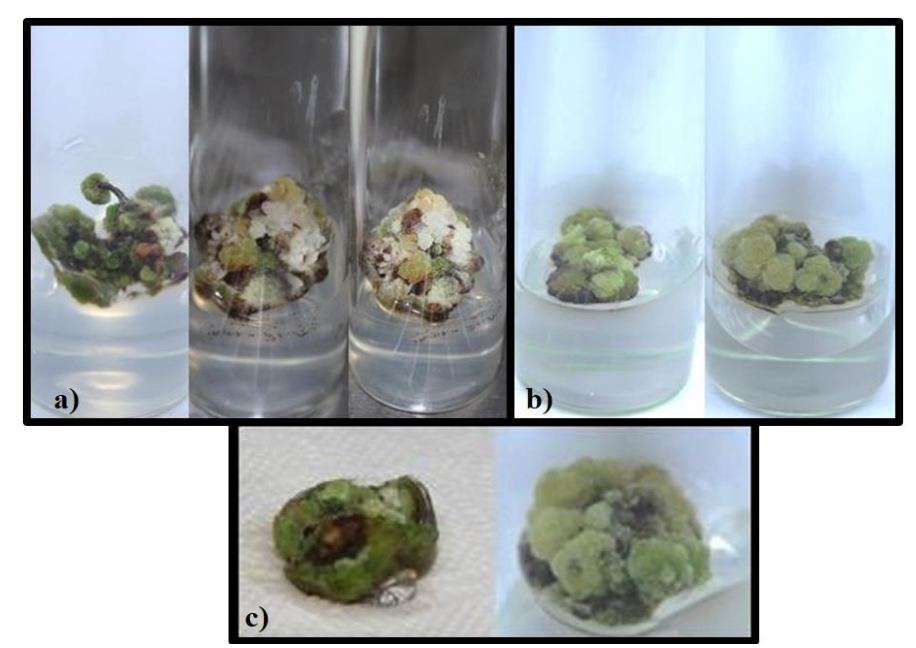

Figure 5. Some callus tissues a) Callus tissues obtained from transverse leaf TCLs, b) Callus tissues obtained from transverse stem segment TCLs, c) Callus tissues obtained from longitudinal body TCLs

1) Results of Transverse Leaf TCL Explants: According to the observations, transverse leaf TCL explants were the explants type with the latest callus formation percentage. The first callus formation took 30 days, while it took 40-45 days to become apparent. While the lowest contamination rate was obtained in N7, N8, N13, N14 and N15 medium with $6.67 \%$, the highest rate was obtained in N6 medium with $33.33 \%$. The lowest darkening percentage was $6.67 \%$ (N5, N7, N8 and N9), and the highest darkening percentage was 26.67\% (N6). When the callus regeneration rates were examined, the lowest rate was observed in N5, N6 and N12 medium as 26.67\%, while the highest regeneration rate was obtained in N16 nutrient medium with $86.67 \%$. Callus regeneration occurred in all medium (Figure 6). 


\begin{tabular}{|c|c|c|}
\hline & $\begin{array}{l}\text { BŞEÜ Fen Bilimleri Dergisi } \\
8(2), 960-977,2021\end{array}$ & $\begin{array}{r}\text { BSEU Journal of Science } \\
\text { https://doi.org/10.35193/bseufbd.947888 }\end{array}$ \\
\hline $\begin{array}{l}\text { BLLECEISSEYHEDEBLI } \\
\text { UNIVERSITESI }\end{array}$ & & 2458-7575 (https://dergipark.org.tr/tr/pub/bseufbd) \\
\hline
\end{tabular}

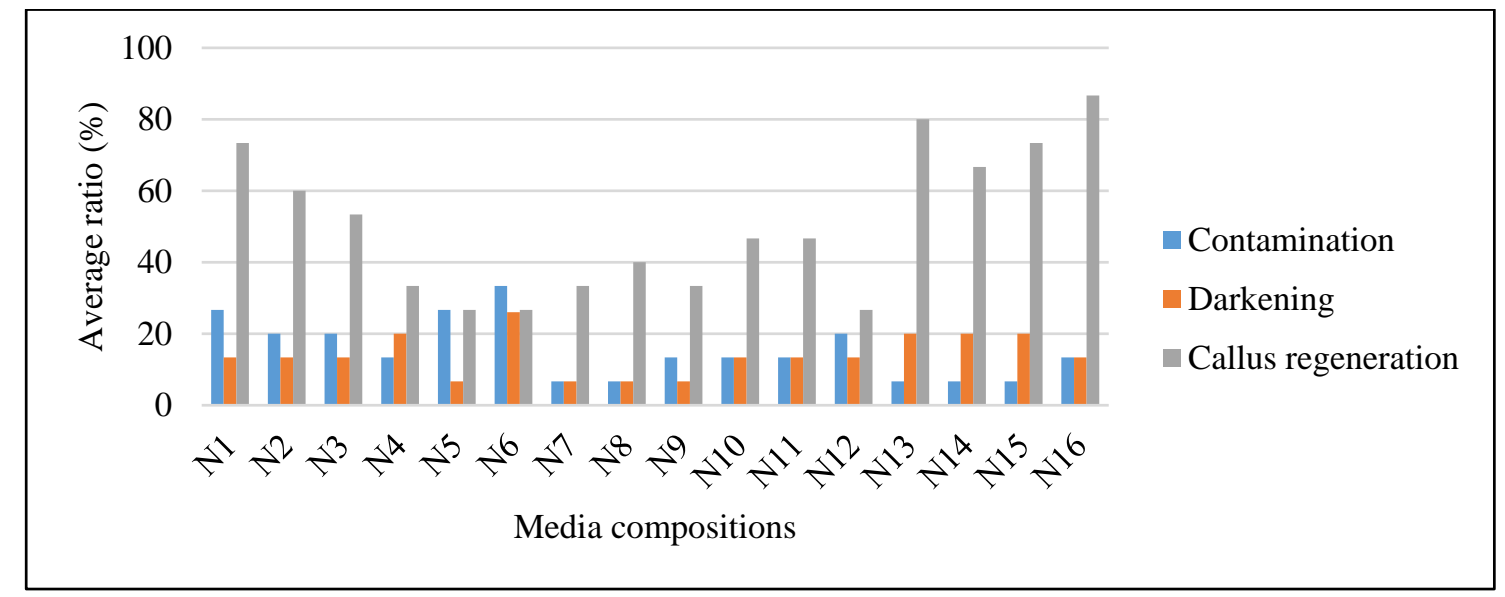

Figure 6. Results of transverse leaf TCL explants

2) Results of transverse stem segment TCL explants: According to the observations, callus formation was observed between 15-20 days. It took about 30-35 days for to get distinct and compact callus. While the lowest contamination percentage was obtained in N5, N6 and N15 medium with 6.67\%, the highest was obtained in N1, $\mathrm{N} 2, \mathrm{~N} 3, \mathrm{~N} 8, \mathrm{~N} 12$ and N14 medium as $20.00 \%$. While the lowest percentage of darkening was obtained in N2, N5, N7, N9, N11 and N12 medium composition with 6.67\%, the highest was obtained in N1, N4, N13, N15 medium as $20.00 \%$. When the calli regeneration rates were compared, the lowest callus regeneration was observed with $26.67 \%$ in N12 medium, while 100\% callus regeneration was observed in N16 medium. Callus regeneration occurred in all medium (Figure 7).

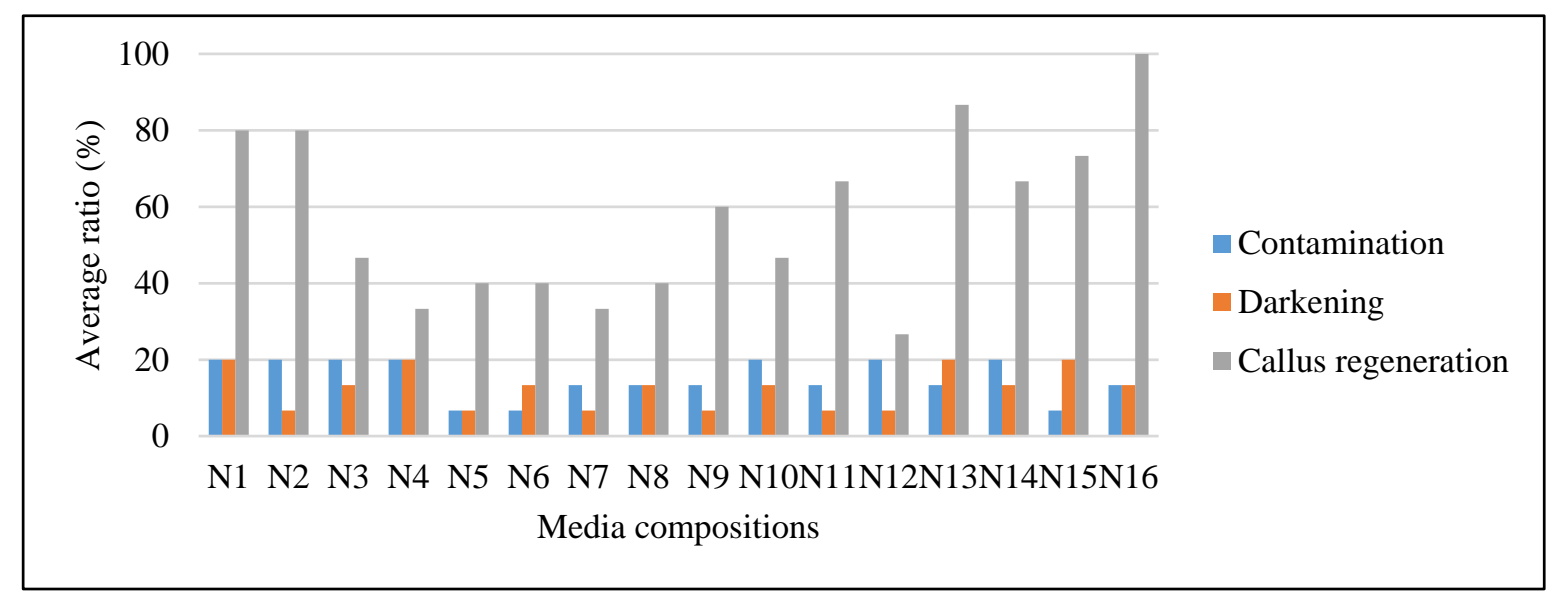

Figure 7. Results of transverse stem segment TCL explants

3) Results of longitudinal node TCL explants: According to the observations, the first callus formation took 30 days, while it took 35-40 days to become apparent. While the lowest contamination rate was obtained in $\mathrm{N} 3, \mathrm{~N} 5, \mathrm{~N} 6, \mathrm{~N} 14, \mathrm{~N} 15$ and N16 medium with $6.67 \%$, the highest rate was obtained in N12 medium with $20 \%$. The lowest darkening percentage was $6.67 \%$ (N2, N5, N7 and N9), and the highest darkening percentage was $20,00 \%$ (N13 and N15). When the callus regeneration rates were examined, the lowest rate was observed in N12 medium as $26.67 \%$, while the highest regeneration rate was obtained in N16 nutrient medium with 100,00\%. Callus regeneration occurred in all medium (Figure 8). 


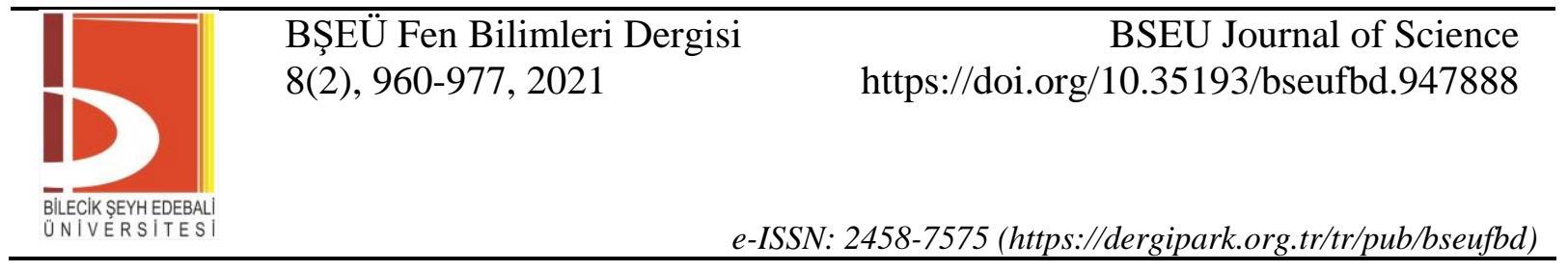

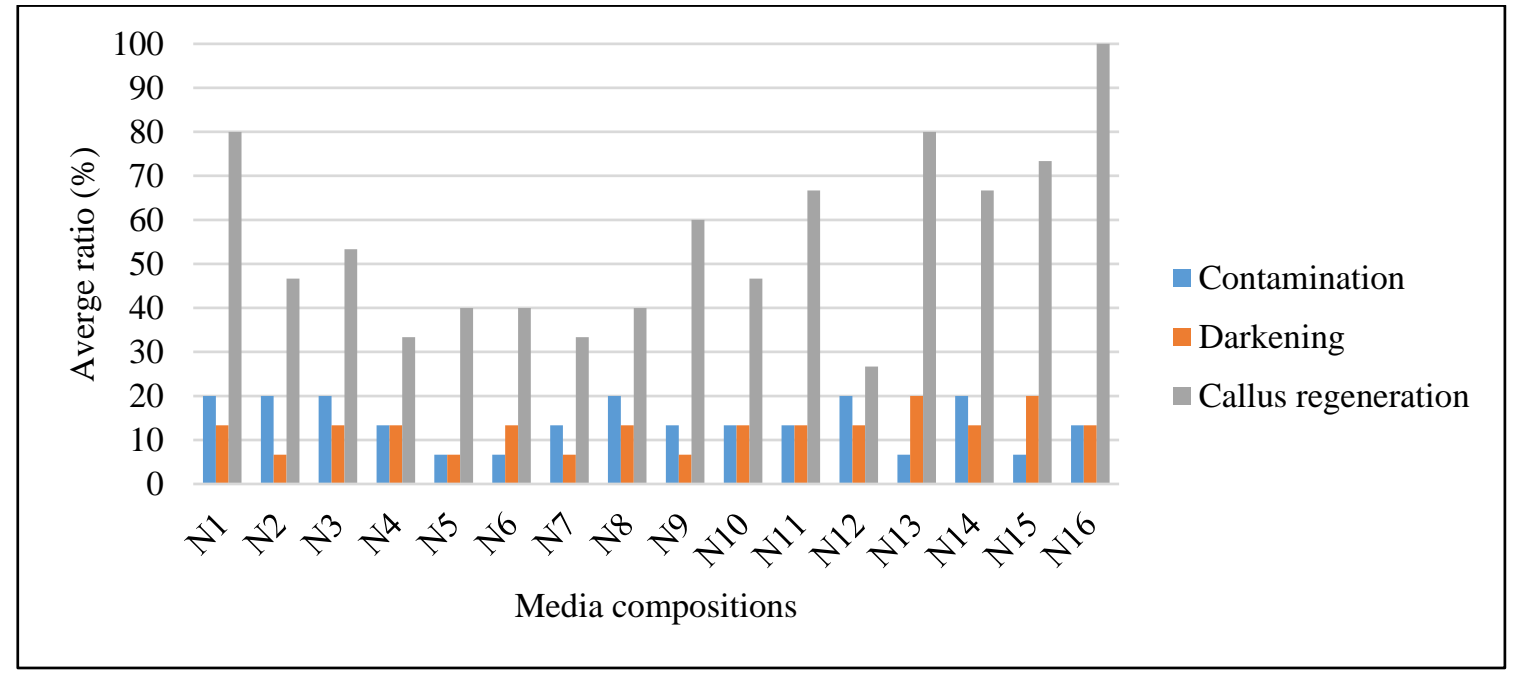

Figure 8. Results of longitudinal node TCL explants

\section{B.Results of Callus Tissue Transfers to Semi-solid Media for Regeneration and Preventing Darkening}

Different basal media have been enriched with $1 \mathrm{mg} / \mathrm{L} \mathrm{2,4-D} \mathrm{and} 1 \mathrm{mg} / \mathrm{L}$ KIN to prevent darkening of lentisk callus tissues and to increase the current callus amount. In the study, different antioxidants were added alone and in different amounts to media, and it was aimed to prevent darkening. The rate of darkening observed in 24 hours and one week period was determined and given in Table 9. The data obtained as a result of the statistical analysis performed were found to be statistically insignificant. Generally, it has been observed that the applications that reduce darkening relatively are with citric acid and ascorbic acid. Unfortunately, PVP and activated carbon applications could not achieve the desired success. In the entire medium, the studies could not be continued because the partially darkening trials were re-subcultured in the same environment, as all of them turned black.

Table 9. Average darkening $(\%)$ ratios of calli after 7 days of culture period $*$

\begin{tabular}{|c|c|c|c|}
\hline \multirow{2}{*}{ Antioxidant code } & \multicolumn{3}{|c|}{ Basal media compositions } \\
\hline & N16 & R16 & W16 \\
\hline $\mathbf{A}$ & 93,33 & 86,67 & 100 \\
\hline $\mathbf{B}$ & 86,67 & 93,33 & 93,33 \\
\hline $\mathbf{C}$ & 86,67 & 93,33 & 100 \\
\hline D & 86,67 & 93,33 & 86,67 \\
\hline $\mathbf{E}$ & 100 & 100 & 100 \\
\hline $\mathbf{F}$ & 93,33 & 86,67 & 86,67 \\
\hline $\mathbf{G}$ & 93,33 & 86,67 & 100 \\
\hline $\mathbf{H}$ & 93,33 & 86,67 & 86,67 \\
\hline $\mathbf{J}$ & 100 & 93,33 & 100 \\
\hline $\mathbf{K}$ & 100 & 100 & 86,67 \\
\hline
\end{tabular}

at the $\mathrm{P}=0.05$ level using the MiniTab program, according to the ANOVA multiple comparison test. 


\begin{tabular}{|c|c|c|}
\hline & $\begin{array}{l}\text { BŞEÜ Fen Bilimleri Dergisi } \\
8(2), 960-977,2021\end{array}$ & $\begin{array}{r}\text { BSEU Journal of Science } \\
\text { https://doi.org/10.35193/bseufbd.947888 }\end{array}$ \\
\hline $\begin{array}{l}\text { BLLECEIKSEYHEDEBLI } \\
\text { UNIVERSITESI }\end{array}$ & & 2458-7575 (https://dergipark.org.tr/tr/pub/bseufbd) \\
\hline
\end{tabular}

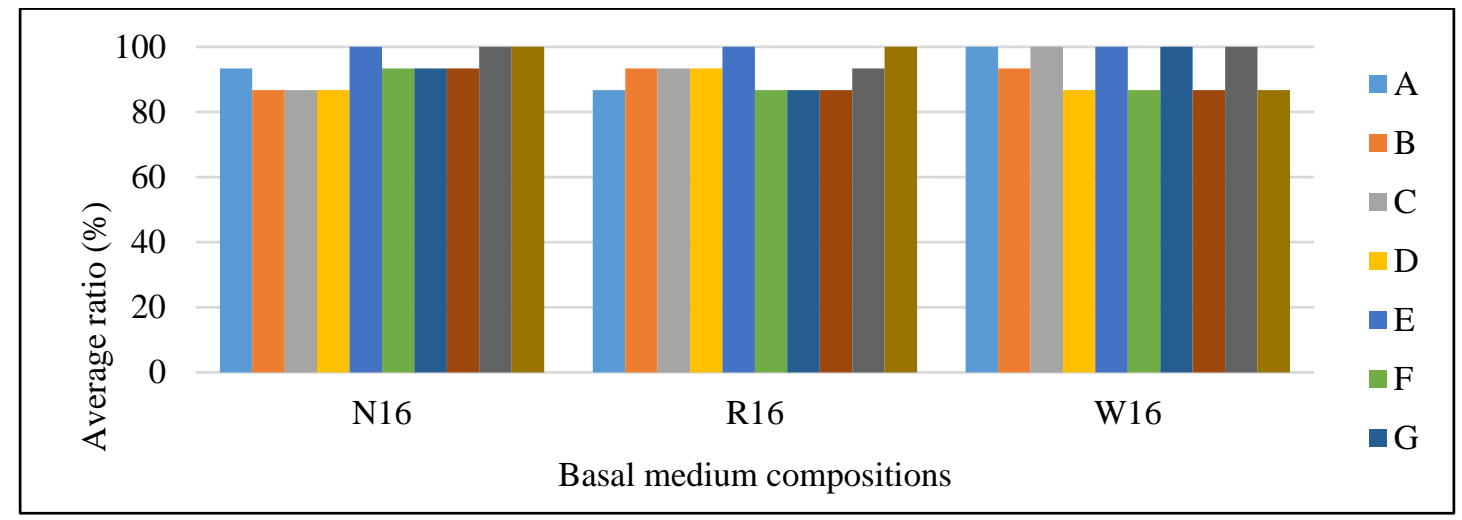

Figure 9. Darkeningratios (\%)in different media compositions including antioxidants

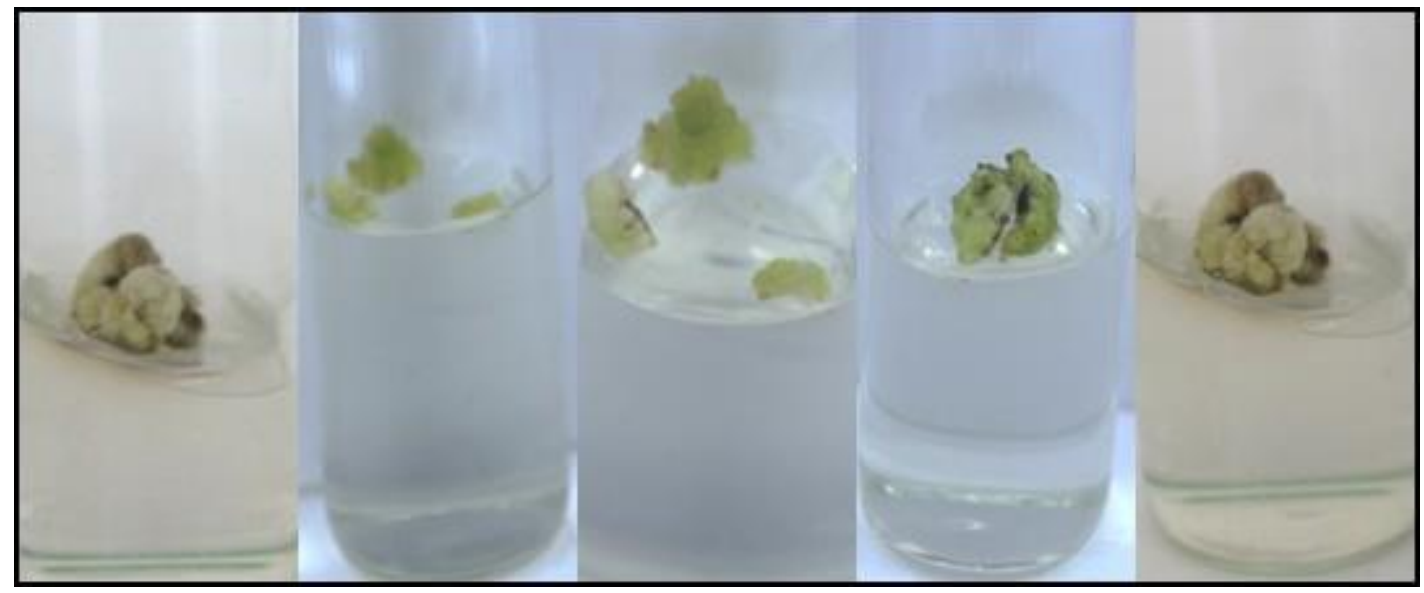

Figure 10. Some callus tissues without darkening

\section{Results of Callus Tissue Transfers to Liquid Media for Inducing Somatic Embryogenesis}

Another experiment established to regenerate lentiks callus tissues was liquid culture. The data obtained from the study are given in Figure 11. According to the results of variance analysis, the difference was found to be insignificant. While it was 33.33\% in MS1I1K1B medium, all of the callus in MS1I, MS1K and MS1I1K medium were darkened. Somatic embryogenesis was not observed for 4 weeks in both the darkened callus and the non-darkening callus.

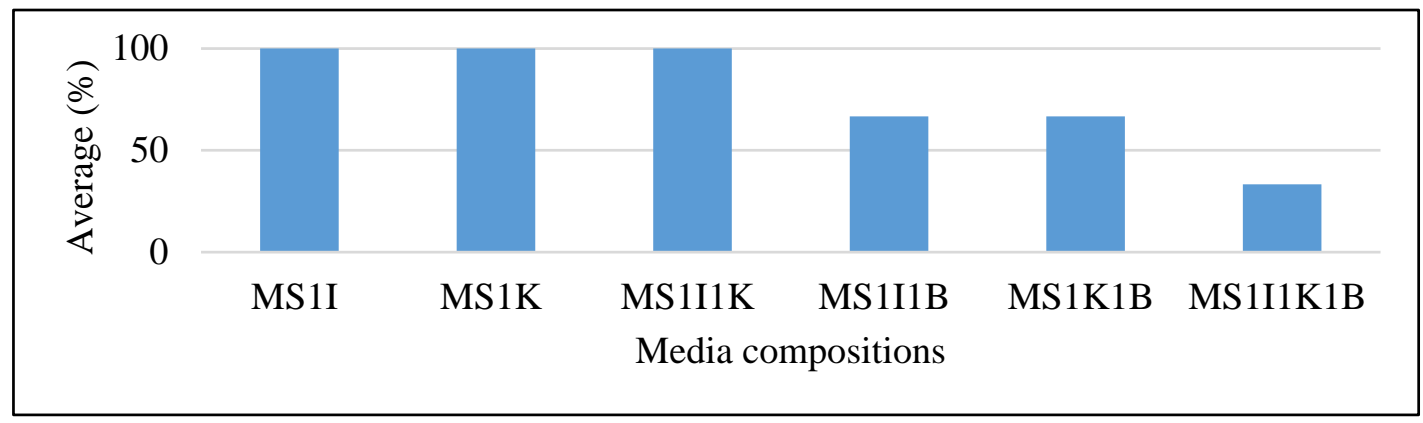

Figure 10. Darkening ratios $(\%)$ of callus tissues in liquid culture experiments in different media

\section{D.Results of Encapsulation}

Considering the sodium alginate coating studies, which is another trial conducted to block darkening, the difference between the blackening status (\%) of the callus was found to be insignificant according to the results of variance analysis. The lowest darkening rate was calculated as $80 \%$, and the highest darkening rate was calculated 
as $100 \%$ (Figure 11). The time to blacken on alginate coated beads ranged from 12 hours to 72 hours. Since necrosis was observed in the beads showing partial darkening, the trials could not be continued.

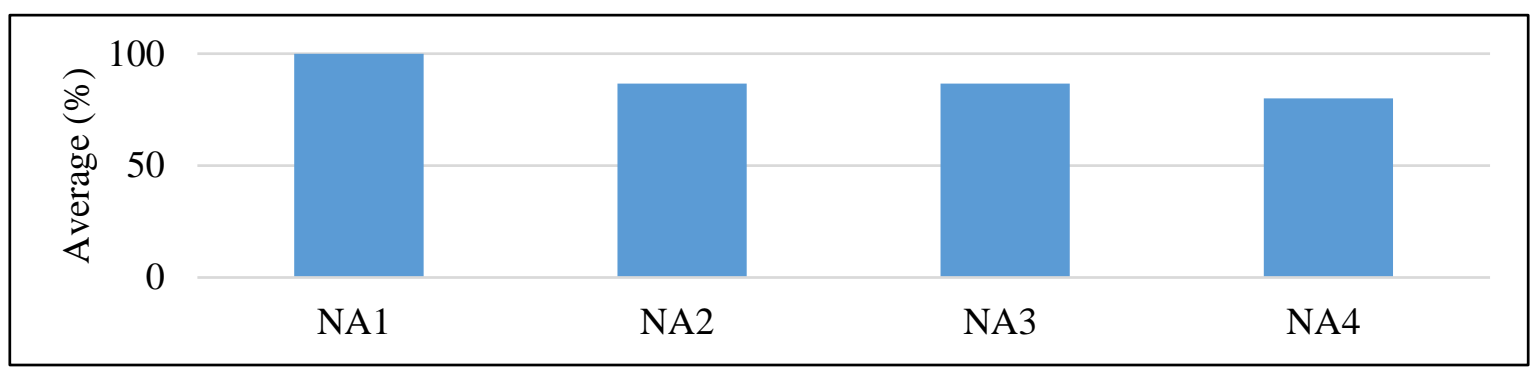

Figure 11. Darkening ratio (\%) of lentisk callus in different encapsulation trials

\section{E. Results of Nurse Cultures}

As a result of the nurse culture performed with Aloe vera L. and Gossypium hirsutum L., the difference in darkening (\%) was found to be significant, while the difference was found to be insignificant according to the variance analysis for contaminated (\%) (Table 10). The percentage of contaminated callus was at least $0 \%$ (PKa) and the highest was 13.33\%, while the lowest percentage of darkening was 53.33\% (PKb) (Figure 12).

Table 10. Average darkening and contamination ratios (\%)of nurse culture at the end of the 2 -week culture period

\begin{tabular}{ccc}
\hline & \multicolumn{2}{c}{ Average } \\
\cline { 2 - 3 } Trial code & Contamination (\%) & Darkening (\%) \\
\cline { 2 - 3 } AVa & 13,33 & $93,33 \mathrm{a}$ \\
AVb & 13,33 & $93,33 \mathrm{a}$ \\
PKa & 0,00 & $66,67 \mathrm{ab}$ \\
PKb & 13,33 & $53,33 \mathrm{~b}$ \\
\hline
\end{tabular}

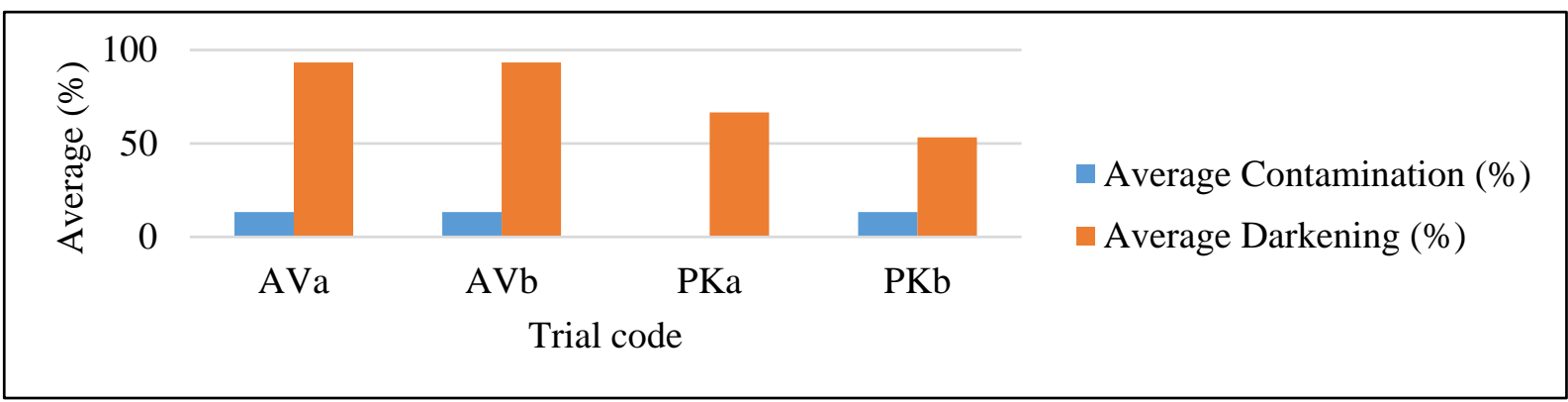

Figure 12. Contamination and darkening ratios (\%)in different nurse culture trials

\section{IV.DISCUSSION AND CONCLUSION}

Pistacia lentiscus $\mathrm{L}$. is a commercial plant with high commercial importance, both with its pleasant scent and its resin. It can be grown commercially only in Chios Island in the world, and especially in Çeşme in Turkey. However, in recent years, agricultural areas have shrunk due to the rapidly increasing tourism investments in the region. As a result, chewing gum production lost its economic importance and the plant was in danger of extinction [40]. It is aimed to increase the production with biotechnological methods as an alternative for this plant, which is very difficult to produce by traditional production methods. Recalcitransience and darkening problem in its production with tissue culture techniques are among the problems that must be overcome. In order to overcome these problems, it was aimed to provide in vitro regeneration with some different techniques such as TCL technique besides classical micropropagation techniques. With the TCL technique, it is aimed to provide more tissue or organ output by using less explant compared to conventional plant tissue techniques. According to the results obtained in this study, which was the first study on the adaptation of the TCL technique to the mastic plant, although the 
expectations were successful at the first stage, it was not possible to completely block the darkening problem despite the different applications made later.

The most commonly used growth regulators in plant tissue culture technology are auxins and cytokines [41].The rate of use of auxin and cytokinin may vary according to what kind of morphogenetic improvement we want. The combined use of 2,4-D (auxin) and KIN (cytokinin) growth regulators in the nutrient medium often stimulates callus formation or somatic embryo formation [42]. In callus culture initiated from different plant parts in Moringa plant, the best callus development was achieved with $5 \mathrm{mg} / \mathrm{L} \mathrm{2,4-D}$ and $0.1 \mathrm{mg} / \mathrm{L}$ in leaf-based tissues [43]. In different tissues taken from the arugula plant, it was said that maximum fresh callus was obtained from cotyledon leaves with the support of $2 \mathrm{mg} / \mathrm{L} \mathrm{2,4-D}$ and $0.5 \mathrm{mg} / \mathrm{L} \mathrm{KIN} \mathrm{[44].} \mathrm{In} \mathrm{a} \mathrm{study} \mathrm{conducted} \mathrm{with} \mathrm{Bacopa}$ monnieri plant, it was reported that the most effective explant species in forming callus tissue was mature leaves and the most effective hormone combination was $1.5 \mathrm{mg} / \mathrm{L} 2.4-\mathrm{D}$ and $0.4 \mathrm{mg} / \mathrm{L} \mathrm{KIN} \mathrm{[45].} \mathrm{In} \mathrm{the} \mathrm{study} \mathrm{conducted}$ by [34], it was stated that the best basic nutrient medium for both root $(80.0 \%$ callus formation percentage) and leaf ( $84 \%$ callus formation percentage) explants in lentisk callus cultures was MS. It has also been reported that 1 $\mathrm{mg} / \mathrm{L} \mathrm{KIN}$ and $1 \mathrm{mg} / \mathrm{L}$ 2,4-D are the best combination as plant growth regulators. Likewise, [35] stated that he got the same results in his research. In the study carried out by [46], the callus regeneration obtained from leaf explants was $80 \%$ and this value was below the value obtained by us. In this study conducted by us, the highest callus formation occurred in cultures initiated from transverse leaf section tissues with $93.33 \%$. The highest callus formation percentage was obtained with the combination of $1 \mathrm{mg} / \mathrm{L} \mathrm{2,4-D}$ and $1 \mathrm{mg} / \mathrm{L} \mathrm{KIN}$ regardless of the explants. This results are similar with [46].

One of the problems seen in plant tissue cultures is darkening problems. In the reproduction of woody plants by tissue culture, blackening that causes the death of explants and tissues is a bottleneck that must be overcome. Color changes rapidly from the cut surfaces during the culture. This darkening is due to the release of phenolic compounds, which are abundant in plants, to the environment. The membrane structure in the tissue separates polyphenol oxidase and phenolic compounds. When the membrane structure in between is damaged, darkening occurs. Vacuoles of healthy cells also contain phenolic compounds, but since the phenol oxidase in the cytoplasm is found in the cytoplasm, blackening does not occur unless the tissue is destroyed [47, 48]. Various anti-darkening agents and mechanisms are used to solve this problem. Darkening of explants cultured in vitro is a serious problem that prevents the effective micropropagation of woody plants [49].Various compounds are used for this purpose, but citric acid and ascorbic acid are the most common. However, in some studies, it is also thought that the use of high ascorbic acid and citric acid can inhibit cell division and embryogenesis. In Protea cynaroides plant, soaked in $100 \mathrm{mg} / \mathrm{L}$ ascorbic acid and $1500 \mathrm{mg} / \mathrm{L}$ citric acid solution for 1 hour [50], $0.5 \mathrm{mg} / \mathrm{L}$ citric acid supplement to the medium in kiwi [51], blackberry explants soaked in a mixture of $60 \mathrm{mg} / \mathrm{L}$ ascorbic acid and 60 $\mathrm{mg} / \mathrm{L}$ citric acid [52] had been stated that it is successful in preventing darkening. In this research, the lowest darkening was determined to be $86 \%$. When examined in detail, it can be stated that mostly ascorbic acid and citric acid application is more successful, while PVP and activated carbon application are relatively less effective. It is thought that this may be due to the use of mature lentisk explants, and that darkening can be reduced much more in younger plants and even seedlings.

Among plant tissue culture techniques, liquid cultures are useful in reducing plant breeding costs and transitioning to automation. In semi-solid cultures, the explant can only take nutrients from the surface it touches and transmit them to other parts of the explant from the transmission bundles with the help of water. In this case, the thought emerged that the vegetative material could not benefit from the environment sufficiently, and its development was negatively affected. Researchers have begun experimenting with liquid cultures to overcome this problem. As a result of these studies, it was seen that the nutrient medium entered the metabolism of the plant not only from the cut part, but also through the stomata and pores, and this situation had a positive effect on growth $[53,54]$. Somatic embryo recovery and/or development of somatic embryos through liquid cultures are found to be effective in various woody plants, tropical plants, etc. Apart from that, it has been stated that nodal explants can perform more than one proliferation cycle when re-cultured in a liquid medium [55]. In the liquid cultures are used with palm plant, while the somatic embryo formation was observed in $52 \%$ of the callus using $2,4-\mathrm{D}$ [56], the reproduction coefficient of 5.97 shoots per explant was reported in the redbud plant [57]. In a study using a bioreactor, it was observed that the alder plant formed axillary shoots in a WPM environment enriched with 0.1 $\mathrm{mg} / \mathrm{L} \mathrm{BAP}$ and $0.5 \mathrm{mg} / \mathrm{L}$ IAA [58]. No positive results were obtained in the experiments where we used different cytokines (BAP and KIN) and auxin (IAA) hormones together or separately. Darkening-induced necrosis was observed without regeneration in shaking liquid cultures without any change. This was thought to be that the 
growth was inhibited due to the tight structure of the callus and/or the exudation of the P. lestiscus var. Chia callus without benefiting from the plant growth regulators.

Synthetic seed; is defined as the synthetic encapsulation of somatic embryo, shoot tip, cell aggregate or other tissues, which can transform into a complete plant in vitro and ex vitro conditions and can continue to show this feature after long-term storage. The basic principle in performing alginate encapsulation; is based on the exchange of $\mathrm{Na}^{+}$ions in the sodium alginate and $\mathrm{Ca}^{+}$ions in $\mathrm{Ca}_{2} \mathrm{Cl}_{2}$ solution when the sodium alginate solution containing plant parts is dropped $\mathrm{Ca}_{2} \mathrm{Cl}_{2}$ solution [59]. Synthetic seed is generally used to propagate non-seed producing plants, transgenic plants, elite species and species difficult to propagate by seed. It is often preferred for short or long term storage. There is no precedent study of the encapsulation trial in the Pistacia lentiscus plant. In some plant species such as Litchi chinensis, it has been reported that somatic embryos and seeds are encapsulated to increase germination and break dormancy [60]. In the synthetic seed study on the Bacopa monnieri plant, it was stated that lowering the oxygen level is beneficial for the storage of seeds [61]. Based on this idea, in this study, it was tried to reduce oxidative stress by reducing the contact of lentisk callus with air. Synthetic seeds obtained as a result of the encapsulation process with the addition of antioxidants turned black after 48 hours. In this context, it was concluded that the antioxidant level was insufficient or that it could be continued to work with other antioxidants.

No studies similar to the nurse cultures made with Aloe vera $\mathrm{L}$. and cotton plant explants have been found in the research. Among the experiements carried out in this study, the most effective method to prevent darkening was the lentisk callus application on the cotton callus. While the purpose of the Aloe vera L. plant is to benefit from the regeneration effect of its unique gel, it has been observed that it is not very effective when applied in two different ways. It was thought that the reason for this was that its healing and regenerative properties were not yet developed or penetrated lentisk callus during tissue culture. In a study with cotton plant callus, it has been suggested that the darkening of lentisk callus can be blocked by the synergistic effect of two different callus structures. While darkening is less in the tissues in direct contact, darkening is less blocked in the culture with filter paper. In this case, it is thought that the filter paper reduces the interaction between them.

Lentisk plants are conventionally produced by seeds. But high heterozygosity and long juvenile period are handicap for conventional breeding process. Furthermore it isn't possible to produce true-to-type with this protocols for all Pistacia species. For this reason, it is necessary to develop different clonal propagation methods, especially for the lentisk plants [62].Micropropagation has accepted as an effective way to achieve clonal propagation of elite clones [63]. It was also stated in the studies that the use of female plants is not suitable for mastic gum production $[64,65]$. In this study, the regeneration responses of different male lentisk explant sources with different auxin/cytokinin (2,4-D/KIN) ratios in the medium were investigated by the TCL technique. All trials produced callus. When the healthy callus was subcultured in a semi-solid medium containing antioxidants, their responses were insufficient. Liquid cultures established in the different mediums have not been beneficial for lentisk callus. The efficiency we wanted could not be obtained from the encapsulated lentisk tissues. In the study, the most successful results in the prevention of blackening were obtained from the experiments of the nurse technique. This method is a pioneer for other studies to prevent darkening.

\section{REFERENCES}

[1] Tianlu, M., \& Barfod, A. (1980). Anacardiaceae, Fl. Flora Reipublicae Popularis Sinicae, 33, 44-109.

[2] Browicz, F.A. (1987). Pistacia lentiscus L. var. Chia (Anacardiacea) on Chios island, Plant Systematics and Evolution, 155(1-4), 189-195

[3] Çalar, N. (2013). Sakiz agacı (Pistacia lentiscus L.)'nin Pistacia anaçları (Pistacia vera L., Pistacia khinjuk Stocks, Pistacia atlantica Desf., Pistacia terebinthus L.) üzerine in vitro mikroasilanmast, Yüksek Lisans Tezi, D.Ü. Fen Bilimleri Enstitüsü, 120.

[4] Onay, A., Yıldırım, H., Uncuoğlu, A. A., Çiftçi, Y. Ö., \& Tilkat, E. (2016). Sakız Ağacı (Pistacia lentiscus L.) Yetiştiriciliği. Dicle Üniversitesi Basımevi, 106.

[5] Perikos, J. (1993). Te Chios Gum Mastic. Print All Ltd. Athens

[6] Akdemir, Ö. F., Tilkat, E., Onay, A., Kılınç, F. M., Süzerer, V., \& Çiftçi, Y. Ö. (2013). Geçmişten Günümüze Sakız Ağacı Pistacia lentiscus L. Batman Üniversitesi Yaşam Bilimleri Dergisi, 3(2), 1-28. 
[7] Kılınç, F. M. (2013). Sakız ăgacı (Pistacia lentiscus L.)'nın in vitro klonal mikroçoğaltılması. Yüksek Lisans tezi, Dicle Üniversitesi, Fen Bilimleri Enstitüsü Biyoloji Anabilim Dalı, Diyarbakır, Türkiye.

[8] Koç, İ. (2011). Sakız ă̆acının (Pistacia lentiscus L.) in vitro koşullarda mikroçoğaltımı ve saklanması, Yüksek Lisans Tezi. Gebze Yüksek Teknoloji Enstitüsü, Kocaeli.

[9] Acar, İ. (1998). (Pistacia lentiscus L. var. Chia.) sakızı üretiminin geliştirilmesine esas olmak üzere sakızın fiziko-kimyasal yönden incelenmesi. Ormancılık Araştırma Ens. Teknik Rap. Ser. No 35.

[10] Ekingen, Z. (2016). P. lentiscus L. Tohumlarının Çimlendirilmesi ile Elde Edilen Aksenik Sürgünlerin TIS Biyoreaktör Sistemi ile Mikroçoğaltılması, Yüksek Lisans tezi, Fırat Üniversitesi, Fen Bilimleri Enstitüsü, Biyoloji Ana Bilim Dalı, Elazı̆̆.

[11] Onay, A., Yıldırım, H., \& Yavuz, M. A. (2016). Sakız Ağacı (Pistacia lentiscus L.) Yetiştiriciliği ve Reçinesi. Batman Üniversitesi Yaşam Bilimleri Dergisi;6(2/2), 133-144.

[12] Ranjan, A., \& Khokhani, D. (2017), Scope and Importance of plant biotechnology in crop improvement, Plant Biotechnology, 1, 27-44.

[13] Ranjan, T., Sahni, S., Prasad, B. D., Kumar, R. R., Rajani, K., Jha, V. K., Sharma, V., Kumar M, \& Kumar, V. (2017). Sterilization technique, In Plant Biotechnology, 1, 69-86.

[14] Aggarwal, D., Kumar, A., \& Kumar, A. (2019). Plant tissue culture for commercial propagation ofeconomically important plants. Industrial Biotechnology: Plant Systems, Resources and Products, De Gruyter, Berlin, 121.

[15] Gürel, A., Hayta, S., Nartop, P., Bayraktar, M. ve Orhan-Fedakar, S., 2013. Bitki Hücre, Doku ve Organ Kültürü Uygulamaları, Ege Üniversitesi Basımevi, 47-66.

[16] Onay, A. (2005). Pistachio (Pistacia vera L.). In Protocol for Somatic Embryogenesis in Woody Plants. Springer, 289-300.

[17] Onay, A. (2003). Micropropagation of pistachio. In Micropropagation of woody trees and fruits, 565-588.

[18] Da Silva J. A., \& Nhut D. T. (2003). Control of plant organogenesis: genetic and biochemical signals in plant organ form and development. In Thin cell layer culture system: regeneration and transformation applications. 135-90.

[19] Tran Thanh Van, M. (1973). In vitro de novo flower, bud, root and callusdifferentiation from excised epidermal tissue, Nature, 246, 44-45.

[20] Tran Thanh Van, M., Dien, N. T., \& Chlyah, A. (1974). Regulation oforganogenesis in small explants of superficial tissue of Nicotiana tabacum L., Planta, 119,149-159.

[21] Tran Thanh Van, K., \& Gendy, C. (1996) Thin cell layer (TCL) method toprogramme morphogenetic patterns, Plant Tissue Culture Manual, 114, 1-25.

[22] Raomai, S., Kumaria, S., Kehie, M., \& Tandon, P. (2015). Plantlet regeneration of Paris polyphylla Sm. via thin cell layer culture and enhancement of steroidal saponins in mini-rhizome cultures using elicitors. Plant growth regulation, $75(1), 341-353$.

[23] Da Silva J. A. (2013). The role of thin cell layers in regeneration and transformation in orchids. Plant Cell, Tissue and Organ Culture (PCTOC), 113(2), 149-161.

[24] Da Silva J. A., Altamura, M. M., \& Dobránszki, J. (2015). The untapped potential of plant thin cell layers. Journal of Horticultural Research, 23(2), 127-131.

[25] Hossain, M. M., Kant, R., Van, P. T., Winarto, B., Zeng, S., Teixeira da Silva, J. A. (2013). The application of biotechnology to orchids. Critical Reviews in Plant Sciences, 32(2), 69-139.

[27] Da Silva J. A. (2003) Thin cell layer technology for induced response and control of rhizogenesis in chrysanthemum. Plant Growth Regul, 39:67-76

[28] Tran Thanh Van M. (2003). Thin cell layer concept. In Thin Cell Layer Culture System: Regenerationand Transformation Applications. 1-16. 
[29] Da Silva J. A. \& Dobránszki, J. (2015). Plant thin cell layers: update and perspectives. Folia Horticulturae, 27(2), 183-190.

[30] Mederos-Molina, S., \& Trujillo, M. I. (1999). Elimination of browning exudateand in vitro development of shoots in Pistacia vera L. cv. mateur and Pistaciaatlantica desf. culture. Acta Societatis Botanicorum Poloniae, 68(1), 21-24.

[31] Tabiyeh, D. T., Bernard, F., \& Shacker, H. (2006). Investigation ofglutathione, salicylic acid and $\mathrm{GA}_{3}$ effects on browning in Pistacia vera shoottips culture. In IV International Symposium on Pistachios and Almonds, 726, 201-204.

[32] Vasconcelos, C. M., Oliveira, E. B., Arantes, L. F., Rossi, S. N., Rocha, R. L., Puschmann, R., \& Chaves, J. B. P. (2020). Antibrowning effect of thecombination of ascorbic, citric and tartaric acids on quality of minimallyprocessed yacon (Smallanthus sonchifolius). Boletim do Centro de Pesquisa de Processamento de Alimentos, 36(2).

[33] Heidari-Zefreh, A. A., Shariatpanahi, M. E., Mousavi, A., \& Kalatejari, S. (2019). Enhancement of microspore embryogenesis induction and plantlet regeneration of sweet pepper (Сарsicum аппиит L.) using putrescine and ascorbic acid. Protoplasma, 256(1), 13-24.

[34] Demir, E. (2018). Aksenik Jüvenil Sakız Ağacı (Pistacia lentiscus L.) Eksplantlarından Kallus Kültürlerinin Başlatılması ve Optimizasyonu. Yüksek lisans tezi, Batman Üniversitesi, Fen Bilimleri Enstitüsü Biyoloji Anabilim Dal, Batman.

[35] Hoşer, A. (2018). Jüvenil Aksenik Sakı Ağacı Eksplantlarından (Pistacia lentiscus L.) Süspansiyon Kültürlerinin Başlatılması ve Optimizasyonu. Yüksek Lisans Tezi, Batman Üniversitesi, Batman.

[36] Koç, I., Onay, A., \& Çiftçi, Y. Ö. (2014). In vitro regeneration and conservation of the lentisk (Pistacia lentiscus L.). Turkish Journal of Biology, 38(5), 653-663.

[37] Murashige, T., \& Skoog, F. (1962) A revised medium for rapid growth and bioassy with tobacco tissue cultures. Physiol. Plant, 15, 473-497.

[38] Lloyd, G., \& McCown, B. (1980). Commercially-feasible micropropagation of mountain laurel, Kalmia latifolia, by use of shoot-tip culture. International Plant Propagator's Society, 30, 421-427.

[39] Rugini, E. (1984). In vitro propagation of some olive (Olea europaea L.) cultivars with different root-ability, and medium development using analytical data from developing shoots and embryos. Scientia Horticulturae, $24,123-134$

[40] Onay, A., Çiftçi, Y. Ö., \& Tilkat, E. (2014). Sakız Ağacının (Pistacia lentiscus L.) Juvenil ve Olgun Eksplantlarının Mikroçoğaltımı, Kriyoprezervasyonu ve Genetik Kararlılığının Belirlenmesi. TUBITAK$1001110 T 941$ Proje Final Raporu.

[41] George, E. F., Hall, M. A., De-Klerk, G. J. (2008). Plant Propagation by Tissue Culture. I. The Background. 3rd Edn. Publ. Springer, Dordercht. The Netherlands. 118- 182

[42] Handayani, R. S., Yunus, I., Sayuti, M., \& Irawan, E. (2019). In Vitro Callus Induction of Durian (Durio zibethinus Murr.) Leaves Using Kinetin and 2, 4- D (Dichlorophenoxyacetic Acid). Journal of Tropical Horticulture, 2(2), 59- 64.

[43] Shittu, O. H., Akaluzia, H. C., \& Chibuogwu, M. O. (2017). A comparison of callus production from Moringa oleifera Lam. Leaf, cotyledon and stemexplants using 2, 4-Dichlorophenoxyacetic acid and kinetin for media supplementation. SAU Science-Tech Journal, 2(1), 1-6.

[44] Hunaish, A. A., \& Almasoody, M. M. M. (2020). Induction of callus onvarious explants of arugula plant (Eruca sativa Mill.) using the growth regulators (2, 4-D andKinetin). Plant Archives, 20(2), 1654-1660.

[45] Kumari, R., (2019). Induction of callus from different explants of Bacopa monnieriand effect of adjuvant on the growth rate of the calli. Indian Journal of Scientific Research, 10(1), 113-121.

[46] Tilkat, E., Onay, A., Ertaş, A., Yılmaz, M. A., \& Asan, H. S. (2018). Pistacia lentiscus L.'un In Vitro Sürgün, Kallus ve Hücre Süspansiyon Kültürlerinde Antikanser Aktivite Gösteren Kimyasal Bileşenlerin Üretilmesi. TUBITAK-1001 114Z842 Proje Final Raporu. 
[47] Mayer, A. M., \& Harel, E. (1979). Polyphenol oxidases in plants. Phytochemistry, 18, 193-215.

[48] El-Gloushy, S. F., Liu, R., \& Fan, H. K., (2020). A complete protocol to reduce browning during coconut (Cocos nucifera L.) tissue culture through shoot tips and inflorescence explants. Plant archives, 20, 21962204.

[49] Thakur, A., \& Kanwar, J. S. (2008). Micropropagation of Wild Pear Pyrus pyrifolia (Burm F.) Nakai. I. ExplantEstablishment and Shoot Multiplication. Notulae Botanicae Horti Agrobotanici Cluj-Napoca, 36, 103-108.

[50] Wu, H. C., \& Du Toit, E. S., (2004). Reducing oxidative browning during in vitro establishment of Protea cynaroides. Scientia horticulturae, 100(1-4), 355-358.

[51] Sui, L., Kong, L., Liu, X., \& Zhang, Y. (2020). Anti-browning in Tissue Culture of 'Donghong'Kiwifruit. Materials Science and. Engineering, 740(1), 012195.

[52] Sabooni, N., \& Shekafandeh, A. (2017). Somatic embryogenesis and plant regeneration of blackberry using the thin cell layer technique. Plant Cell, Tissue and Organ Culture (PCTOC), 130(2), 313-321.

[53] Akdemir, H., \& Onay, A., (2017). Biotechnological Approaches for Conservation of the Genus Pistacia. In Biodiversity and Conservation of Woody Plants, 221-244.

[54] Etienne, H., \& Berthouly, M. (2002). Temporary immersion systems in plant micropropagation. Plant Cell, Tissue and Organ Culture, 69(3), 215-231.

[55] Aguilar, M. E., Garita, K., Kim, Y. W., Kim, J. A., \& Moon, H. K. (2019). Simple Protocol for the Micropropagation of Teak (Tectona grandis Linn.) in SemiSolid and Liquid Media in RITA® Bioreactors and ex Vitro Rooting. American Journal of Plant Sciences, 10(7), 1121-1141.

[56] Monteiro, T. R., Freitas, E. O., Nogueira, G. F., \& Scherwinskipereira, J. E. (2017). Assessing the influence of subcultures and liquid medium during somatic embryogenesis and plant regeneration in oil palm (Elaeis guineensis Jacq.). J. Hortic. Sci. Biotechnol. 93, 196-203.

[57] Sezen, M. (2020). Cercis siliquastrum L. bitkisinin RITA® biyoreaktörlerinde In Vitro Mikroçoğaltımı. Ege Üniversitesi Fen Bilimleri Enstitüsü Biyomühendislik Anabilim Dal Yüksek Lisan Bitirme Tezi, İzmir.

[58] San José, M. C., Blázquez, N., Cernadas, M. J., Janeiro, L. V., Cuenca, B., Sánchez, C., \& Vidal, N. (2020). Temporary immersion systems to improve alder micropropagation. Plant Cell, Tissue and Organ Culture (PCTOC), 143(2), 265-275.

[59] Chandra, K., Pandey, A., \& Kumar, P. (2018). Synthetic Seed-Future Prospect in Crop Improvement. International Journal og Agriculture Innovations and Research. 6(4), 120-125.

[60] Das, D. K., Rahman, A., Kumari, D., \& Kumari, N. (2016). Synthetic seed preparation, germination and plantlet regeneration of Litchi (Litchi chinensis Sonn.). American Journal of Plant Sciences, 7(10), 13951406.

[61] Sharma, N., Gowthami, R., Pandey, R., \& Agrawal, A. (2020). Influence of explant types, non-embryogenic synseed and reduced oxygen environment on in vitro conservation of Bacopa monnieri (L.) Wettst. In Vitro Cellular \& Developmental Biology-Plant, 1-6.

[62] Kılınç, F. M., Süzerer, V., Çiftçi, Y. Ö., Onay, A., Yıldırım, A., Uncuoğlu, A. A., Tilkat, E., Koç, İ., Akdemir, Ö. F., \& Metin, Ö. K. (2014). Clonal micropropagation of Pistacia lentiscus L. and assessmentof genetic stability using IRAP markers. Plant Growth Regulators. 75(1), 75-88

[63] Onay, A., Tilkati E., Yıldırım, H., \& Süzerer, V. (2007). Indlrect somatic embryogenesis from mature embryocultures of Pistacia vera L. Propagation of Omamental Plants, 7(2), 68-74.

[64] Yildirım, H. (2012). Micropropagation of Pistacia lentiscus L. from axenic seedling-derived explants. Scientia Horticulturae, 137, 29-35.

[65] Yıldırım, H., Onay, A., Gündüz, K., Ercisli, S., \& Karaat, F. E. (2019). An improved micropropagation protocol for lentisk (Pistacia lentiscus L.). Folia Horticulturae, 31(1), 61-69. 